\title{
Isolation and Chemical Characterization of the Sheath from the Cyanobacterium Chroococcus minutus SAG B.41.79
}

\author{
By SHIBA P. ADHIKARY, ${ }^{1} \dagger$ JÜRGEN WECKESSER, ${ }^{1}$ * \\ UWE J. JÜRGENS, ${ }^{1}$ JOCHEN R. GOLECKI ${ }^{1}$ AND \\ DIETMAR BOROWIAK ${ }^{2}$ \\ ${ }^{1}$ Institut für Biologie II, Mikrobiologie, der Albert-Ludwigs-Universität, Schänzlestr. 1, \\ D-7800 Freiburg i.Br., Federal Republic of Germany \\ ${ }^{2}$ Max-Planck-Institut für Immunbiologie, Stübeweg 51, D-7800 Freiburg i.Br., \\ Federal Republic of Germany
}

(Received 3 February 1986; revised 28 April 1986)

\begin{abstract}
The sheath of the unicellular cyanobacterium Chroococcus minutus SAG B.41.79 was isolated from a crude cell envelope fraction by discontinuous sucrose gradient centrifugation, and was further purified by treatment with lysozyme followed by Triton X-100 or sodium dodecyl sulphate (SDS) extraction. The absence of muramic and diaminopimelic acids and of $\beta$-hydroxy fatty acid showed the fraction to be free from cell wall components. The sheath had a fibrillar fine structure with the fibres parallel to the cell surface.The total neutral sugar content was $45.9 \%(\mathrm{w} / \mathrm{w})$. The main sugars were glucose and 2-O-methyl-6-deoxyhexose. Additional $O$ methyl sugars, 2-O-methylhexose, 3-O-methylhexose and a 2-O-methyl sugar (not further identified), were present. Protein could not be completely removed from the sheath fraction by treatment with boiling SDS. The contents of fatty acids, phosphorus, uronic acids and glucosamine in the fraction were all less than $0.5 \%(\mathrm{w} / \mathrm{w})$.
\end{abstract}

\section{INTRODUCTION}

Many cyanobacteria bear one or more additional layers of considerable thickness external to their outer membrane. These layers have been variously named as cell wall layers, sheath, capsule or slime (Stanier \& Cohen-Bazire, 1977). Unicellular cyanobacteria such as Gloeobacter, Gloeothece or Gloeocapsa (synonym Chroococcus) show light- and electron-microscopically visible sheath layers which enclose both individual cells and cell groups (Rippka et al., 1979). Nothing is known about the chemical composition, physical properties or function of the sheath of unicellular cyanobacteria. Schrader et al. $(1982 a)$ have shown that the isolated sheath of Chlorogloeopsis PCC 6912, which has a rather complex developmental cycle, is composed of mainly neutral sugars and protein but lacks fatty acids. The present work describes the isolation and first chemical characterization of the sheath of the unicellular Chroococcus minutus SAG B.41.79.

\section{METHODS}

Organism and growth conditions. Chroococcus minutus (Kützing) Nägeli strain SAG B.41.79 was obtained from the Sammlung von Algenkulturen, Göttingen, FRG. Cells were grown photoautotrophically in BG-11 medium, pH 7.5 (Rippka et al., 1979) at $25^{\circ} \mathrm{C}$, irradiated continuously with white light from a fluorescent lamp (1-4 klx). Mass cultures were prepared in a 121 fermenter (Jungkeit, Göttingen, FRG) gassed continuously by a stream of air $/ \mathrm{CO}_{2}\left(99: 1, \mathrm{v} / \mathrm{v}\right.$, at $\left.2501 \mathrm{~h}^{-1}\right)$. The generation time was $38 \mathrm{~h}$. Cells were harvested after $18-20 \mathrm{~d}$ growth, washed once with $20 \mathrm{mM}$-Tris/ $\mathrm{HCl}$ buffer $\left(\mathrm{pH} \mathrm{8.0)}\right.$ ) and stored at $-20^{\circ} \mathrm{C}$ until use. This buffer was used also throughout the sheath isolation procedure.

† Present address: Dharanidhar College, 758001-Keonjhar, Orissa, India. 
Isolation of the sheath. Cells were suspended in buffer (as above), mixed with $0.25 \mathrm{~mm}$ diameter glass beads (cell to glass bead ratio $1: 2, \mathrm{v} / \mathrm{v}$ ) and DNAase (approx. $2 \mathrm{mg}$ ) and were broken at $4{ }^{\circ} \mathrm{C}$ in a Vibrogen shaker (Type V12, Edmund Bühler, Tübingen, FRG) at maximum speed for $2 \mathrm{~h}$. After removal of the glass beads by filtration, crude sheath fractions were separated by centrifugation at $750 \mathrm{~g}, 4^{\circ} \mathrm{C}$, for $30 \mathrm{~min}$. The supernatant was then centrifuged at $12100 \mathrm{~g}, 4^{\circ} \mathrm{C}$, for $45 \mathrm{~min}$, and the sediment was washed four times (same conditions). Discontinuous sucrose gradients $(10 \mathrm{ml}$ of $60 \%$, and $5 \mathrm{ml}$ each of $55,50,45$, and $40 \%, \mathrm{w} / \mathrm{w}$, sucrose in Tris/HCl buffer) were loaded with the sediment of the last centrifugation and run in a swing-out rotor model A4.13 (Hermle, Gosheim, FRG) at $16300 \mathrm{~g}, 4^{\circ} \mathrm{C}$, for $4 \mathrm{~h}$. Sheaths were recovered from the $60 \%$ sucrose band and further purified once on the same type of gradient. The sheath fraction was finally washed four times at $12100 \mathrm{~g}, 4^{\circ} \mathrm{C}$, for $45 \mathrm{~min}$, in Tris/ $\mathrm{HCl}$ buffer as above.

To remove cell wall contaminants, the sheath fractions were treated with hen eggwhite lysozyme (EC 3.2.1.17) ( $5 \mathrm{mg}$ in $25 \mathrm{ml}$ ammonium acetate buffer, $\mathrm{pH} 6.8,37^{\circ} \mathrm{C}, 12 \mathrm{~h}$ ) followed by extraction with Triton X-100 ( $2 \%$, w/v, in $0.01 \mathrm{M}-\mathrm{Na}_{2}$ EDTA and $0.01 \mathrm{M}-\mathrm{MgCl}_{2}$, room temperature, $20 \mathrm{~min}$ ) or sodium dodecyl sulphate (SDS) (4\%, w/v, in Tris/ $\mathrm{HCl}$ buffer, $\left.\mathrm{pH} 7 \cdot 8,100^{\circ} \mathrm{C}, 15 \mathrm{~min}\right)$. The purified sheath fractions were finally washed seven times with distilled water $\left(12000 \mathrm{~g}, 4^{\circ} \mathrm{C}\right.$, for $\left.45 \mathrm{~min}\right)$, dialysed, collected by centrifugation $\left(12000 \mathrm{~g}, 4^{\circ} \mathrm{C}\right.$, for $\left.45 \mathrm{~min}\right)$ and lyophilized.

Electron microscopy. Whole cells (freshly harvested) or isolated sheath fractions were fixed in $1 \%(\mathrm{w} / \mathrm{v})$ osmium tetroxide, dehydrated in alcohol and polymerized in Epon according to standard procedures (Kellenberger et al., 1958; Golecki, 1977). Ultra-thin sections were mounted on Formvar-coated copper grids and stained with uranyl acetate (Watson, 1958) followed by lead citrate (Reynolds, 1963). Specimens were examined in a Philips EM 400 microscope at $80 \mathrm{kV}$.

Chemical analyses. Hydrolysis of carbohydrates and polypeptides and the determination of monomers have been described elsewhere (Schrader et al., 1982 b). The neutral sugars were separated by thin-layer chromatography (solvent: ethyl acetate/pyridine/water, 12:5:4, by vol.) and by gas-liquid chromatography as alditol acetate derivatives (Varian Aerograph, model 1400-1, ECNSS-M $2 \mathrm{~mm} \times 1.5 \mathrm{~m}$ glass column, $3 \%$ on Gas-Chrom Q, 100-200 mesh). Mass spectrometric analysis of sugar alditol acetates (reduced with $\mathrm{NaB}^{2} \mathbf{H}_{4}:$ Schmidt et al., 1980) was done in a Finnigan MAT GC/MS automatic system, model 120 . Alditol acetates of hydrolysates $(0 \cdot 1 \mathrm{M}-\mathrm{HCl}$, $100^{\circ} \mathrm{C}, 48 \mathrm{~h}$ ) were separated on a fused silica capillary column SE-54 (25 m, i.d. 0.25 mm). Column temperature

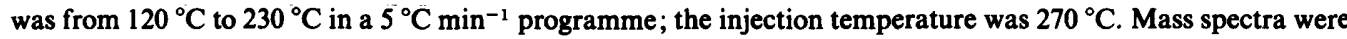
taken at $70 \mathrm{eV}$ in the mass range $43-400 \mathrm{~m} / \mathrm{e}$ in $1 \mathrm{~s}$. Fatty acids were estimated as methyl esters by gas-liquid chromatography (EGSS-X column, $15 \%$ on Gas-Chrom P, 100-200 mesh; or Castorwax column, $2.5 \%$ on

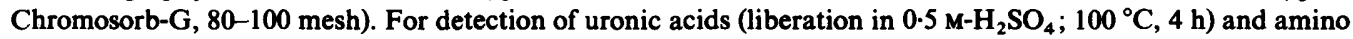
sugars (liberation in $4 \mathrm{M}-\mathrm{HCl}, 110^{\circ} \mathrm{C}, 16 \mathrm{~h}$ ) high-voltage electrophoresis was performed (Kickhöfen \& Warth, 1968). Paper electropherograms were stained with alkaline silver nitrate (Trevelyan et al., 1950). Quantitative determination of amino sugars and amino acids was done in an automatic amino acid analyser (Durrum, model D500). Organic phosphorus was determined according to Lowry et al. (1954).

\section{RESULTS}

\section{Isolation of sheath}

Various cell homogenization methods such as Ultra-turrax, ultrasonication, French press or Vibrogen shaker were applied for breaking C. minutus SAG B.41.79 cells. The best results were obtained using the Vibrogen shaker followed by differential centrifugation of the cell homogenate. A thick gelatinous sheath fraction, together with some whole cells and cell fragments, was obtained in the sediment after centrifugation at $3020 \mathrm{~g}$ for $30 \mathrm{~min}$. This was further purified by centrifugation on a discontinuous sucrose gradient (see Methods). The sheath fraction was obtained from the gradient with a yield of about $28 \%$ on a cell dry weight basis and it appeared to be almost free from unbroken cells and cell debris under the light microscope (Fig. 1). Residual contaminating cell wall components were removed by treatment with lysozyme (Fuhs, 1985; Jensen \& Sicko, 1971) and detergents. Both the outer and cytoplasmic membranes from cyanobacteria can be solubilized with hot SDS (Golecki \& Drews, 1974; Golecki, 1977). Triton X-100 removes the cytoplasmic membrane in Gram-negative bacteria (Schnaitman, 1971). By applying these methods, the sheath fraction of $C$. minutus was obtained free of diaminopimelic and muramic acids, indicating the absence of cell wall. The lack of pigments indicated the fraction to be free of membranes. The yields were $17.7 \%$ (lysozyme + Triton $\mathrm{X}$ 100 ) and $12 \cdot 4 \%$ (lysozyme + SDS) on a cell dry weight basis. 


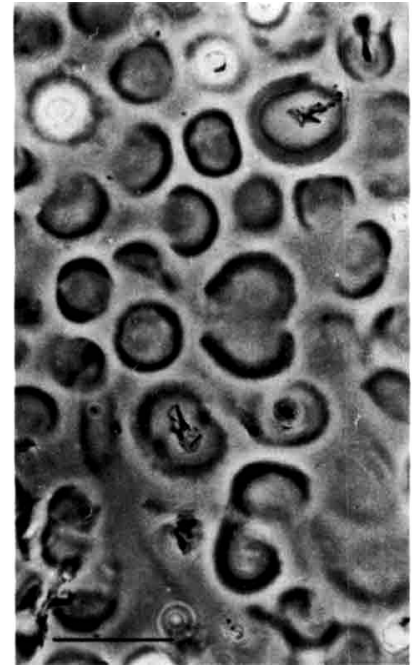

Fig. 1
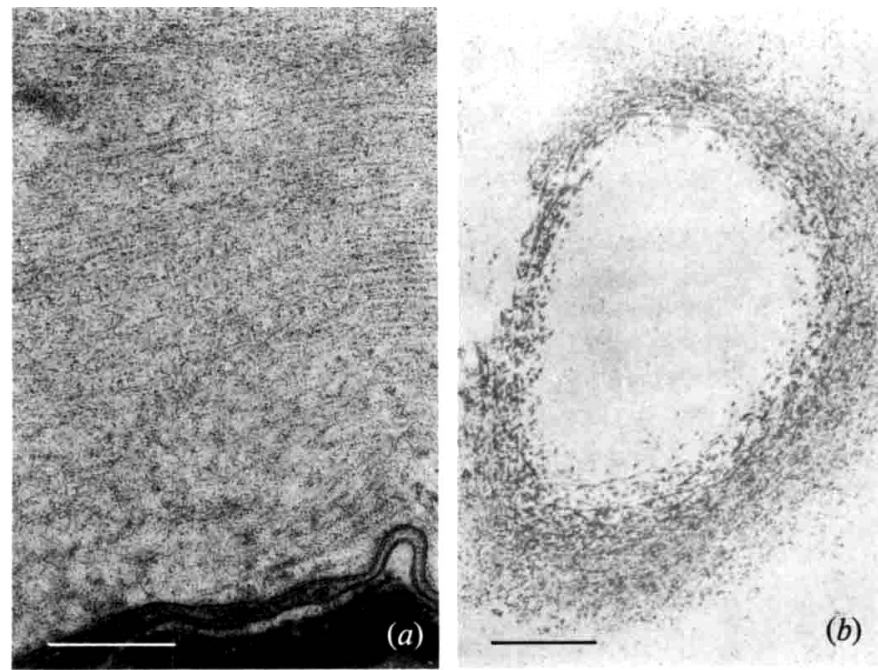

Fig. 2

Fig. 1. Light micrograph of isolated sheath fraction of $C$. minutus (gradient purified, see text). Bar, $2 \cdot 5$ $\mu \mathrm{m}$.

Fig. 2. Ultrathin sections. (a) Part of a whole cell. Note the osmiophilic, fibrillar fine structure of the sheath, the fibres lying parallel to the cell surface. Bar, $200 \mathrm{~nm}$. (b) Isolated sheath fraction purified by gradient centrifugation followed by lysozyme treatment and SDS extraction (see text). Bar, $1 \mu \mathrm{m}$.

Table 1. Chemical analysis of sheath fractions of C. minutus SAG B.41.79

\begin{tabular}{|c|c|c|c|}
\hline & \multicolumn{3}{|c|}{$\begin{array}{l}\text { Content ( } \% \text { of fraction dry wt) } \\
\text { in sheath fraction: }\end{array}$} \\
\hline ent & $\begin{array}{c}\text { From } \\
\text { sucrose } \\
\text { gradient }\end{array}$ & $\begin{array}{c}\text { After lysozyme } \\
+ \text { Triton X-100 } \\
\text { treatment }^{\bullet}\end{array}$ & $\begin{array}{c}\text { After lysozyme } \\
\text { + SDS } \\
\text { treatment } \dagger\end{array}$ \\
\hline
\end{tabular}

Unknown anhydro sugar
2-O-Methyl-6-deoxyhexose
2-O-Methyl sugar (not
further identified)
2-O-Methylhexose
3-O-Methylhexose
Glucose
Total amino acids

$1 \cdot 7$
$6 \cdot 2$
trace

$3 \cdot 3$
$3 \cdot 6$
$7 \cdot 8$
$12 \cdot 6$

$2 \cdot 6$
$9 \cdot 7$
$1 \cdot 0$

$5 \cdot 2$
$4 \cdot 3$
$10 \cdot 8$
ND$$
1.4
$$$$
6 \cdot 7
$$$$
7 \cdot 0
$$$$
15 \cdot 0
$$

ND, Not determined.

* Lysozyme: $5 \mathrm{mg}$ in $25 \mathrm{ml}$ ammonium acetate buffer pH $6.8 ; 37^{\circ} \mathrm{C}, 12 \mathrm{~h}$. Triton $\mathrm{X}-100: 2 \%(\mathrm{w} / \mathrm{v})$ in $0.01 \mathrm{M}-\mathrm{Na}_{2}$ EDTA and $0.01 \mathrm{M}-\mathrm{MgCl}_{2}$; room temperature, $20 \mathrm{~min}$.

† Lysozyme: as above. SDS: $4 \%(w / v)$ in Tris/ $\mathrm{HCl}, \mathrm{pH} 7.8 ; 100^{\circ} \mathrm{C}, 15 \mathrm{~min}$.

\section{Fine structure of the sheath}

Ultrathin sections of cells of $C$. minutus revealed the sheath as an osmiophilic fibrous material with an orientation parallel to the cell surface (Fig. $2 a$ ). The isolated sheath showed a similar fine structure stainable with osmium tetroxide in ultrathin sections (Fig. $2 b$ ).

\section{Chemical analyses}

Neutral sugars were the major components of the sheath fraction (Table 1); their content increased from $22.6 \%$ (gradient-purified) to $33.6 \%$ (lysozyme + Triton X-100) and $45.9 \%$ (lysozyme + SDS). All the fractions contained glucose and the four $O$-methyl sugars, 
Table 2. Retention times and mass-spectrometric fragmentation pattern of $O$-methyl sugars (as alditol acetates) of the sheath of C. minutus SAG B.41.79

\begin{tabular}{|c|c|c|}
\hline$O$-Methyl sugar & $\begin{array}{l}\text { Retention time } \\
\text { (relative to xylose)* }\end{array}$ & $\begin{array}{l}\text { Primary fragments/ } \\
\text { secondary fragments }\end{array}$ \\
\hline Unknown anhydro sugar & 0.66 & $\begin{array}{l}74 \text {; other main fragments: } \\
158,129,113,87,81,69 \dagger\end{array}$ \\
\hline $\begin{array}{l}\text { 2-O-Methyl-6-deoxyhexose } \\
\text { 2-O-Methyl sugar (not further characterized) } \\
\text { 2-O-Methylhexose } \\
\text { 3-O-Methylhexose }\end{array}$ & $\begin{array}{l}0.88 \\
1.09 \\
1 \cdot 19 \\
1 \cdot 22\end{array}$ & $\begin{array}{l}118,275 / 215,201,173,129,99 \\
245 \ddagger, 118 / 203,171 \\
333,118 / 273,259,171,157,139 \\
261,190 / 201,159,141,130\end{array}$ \\
\hline
\end{tabular}

2-O-methyl-6-deoxyhexose, a 2-O-methyl sugar (not further identified), a 2-O-methylhexose and a 3-O-methylhexose, detected by gas-liquid chromatography. The $O$-methyl sugars were identified by their fragmentation patterns on mass spectrometric analysis after separation of their alditol acetate derivatives (Table 2; for a comparison see Jansson et al., 1976). Uronic acids, glucosamine, fatty acids and phosphorus were detected only in trace amounts (each below $0.5 \%$ ) in the sheath fractions. The amino acid content was reduced from $12.6 \%$ (gradient purified) to $5.8 \%$ after lysozyme + SDS treatment (Table 1). A high proportion of aspartic acid, glutamic acid and leucine was observed in the sheath fractions (not shown).

\section{DISCUSSION}

The sheath of $C$. minutus SAG B.41.79 had a high density, which facilitated its separation from the cell homogenate. A similar property was observed with the sheath of Chlorogloeopsis PCC 6912, which on sucrose gradient centrifugation appeared to be even heavier (Schrader et al., 1982a). The sheath of $C$. minutus showed a fibrillar fine structure similar to that of Chlorogloeopsis PCC 6912 (Schrader et al., 1982 a), Gloeocapsa NS4 (Cox et al., 1981), Gloeothece PCC 73107 (Vaara, 1982) and Chroococcus S24, N41 (Potts et al., 1983), with the fibres lying parallel to the outer surface of the cell.

The isolated sheath fraction of $C$. minutus SAG B.41.79 mainly consisted of carbohydrates. The polysaccharides were not solubilized even after extraction with Triton X-100 or boiling SDS. Polysaccharides are common constituents of cyanobacterial cell envelopes (Dunn \& Wolk, 1970; Drews \& Weckesser, 1982; Schrader et al., $1982 a, b$ ). Electron microscopic observations also suggested that the sheath of the coccoid unicellular ensheathed cyanobacterium Gloeocapsa NS4 (Cox et al., 1981) was composed of acidic mucopolysaccharides, staining being observed only with uranyl acetate. Glucose was also reported as the main sugar in the polysaccharide moiety of the sheath of Anabaena cylindrica (Dunn \& Wolk, 1970) and Chlorogloeopsis PCC 6912 (Schrader et al., 1982 a). However, galactose, mannose, xylose and arabinose, found in the sheath fractions of the latter species, were not detected in the sheath of $C$. minutus SAG B.41.79, which contained a number of $\mathrm{O}$-methyl sugars, (2-O-methylhexose, 3-O-methylhexose, 2-Omethyl-6-deoxyhexose and an unknown 2-O-methyl sugar). The relative ratios of the sugars changed little even when drastic methods were used for purification of the sheath (Table 1). $O$ methyl sugars are characteristic constituents of $\mathrm{O}$-antigens of a number of phototrophic bacteria and cyanobacteria (Weckesser et al., 1979) but they were not found in the isolated sheath of Chlorogloeopsis PCC 6912 (Schrader et al., 1982 a) or A. cylindrica (Dunn \& Wolk, 1970). Recently the isolated sheaths of two other coccoid unicellular cyanobacteria, Gloeothece PCC 6909 and Gloeothece PCC 6501, were found to contain a 2-O-methylpentose and 2-Omethylxylose, respectively (S. P. Adhikary \& C. Broll, unpublished). 
The sheath of $C$. minutus SAG B.41.79 contained negligible amounts of fatty acids, as found for sheath fractions of A. cylindrica (Dunn \& Wolk, 1970) and Chlorogloeopsis PCC 6912 (Schrader et al., 1982a). These results give no indication of the presence of glycolipids in cyanobacterial sheaths. All the sheath fractions obtained from $C$. minutus SAG B.41.79 contained considerable amounts of protein(s), which could not be completely solubilized by extraction with hot SDS. This, together with the finding of protein(s) in sheath fractions of $A$. cylindrica (Dunn \& Wolk, 1970) and Chlorogloeopsis PCC 6912 (Schrader et al., 1982 a) indicates ihat protein(s) may be constituent(s) of the sheath of cyanobacteria; proof has not yet been obtained, however.

The authors thank R. Warth for amino acid and amino sugar analyses and $H$. Falk for light micrographs. The work was supported by the Deutsche Forschungsgemeinschaft.

\section{REFERENCES}

Cox, G., Benson, D. \& Dwarte, D. M. (1981). Ultrastructure of a cave-wall cyanophyte - Gloeocapsa NS4. Archives of Microbiology 130, 165-174.

Drews, G. \& WeCkesser, J. (1982). Function, structure and composition of cell wall and external layers. In The Biology of Cyanobacteria, pp. 333-357, Edited by N. G. Carr \& B. A. Whitton. Oxford: Blackwell Scientific Publications.

DunN, J. H. \& Wolk, C. P. (1970). Composition of cellular envelopes of Anabaena cylindrica. Journal of Bacteriology 103, 153-158.

FuHs, G. W. (1958). Enzymatischer Abbau der Membranen von Oscillatoria amoena (Kütz) Gomont mit Lysozym. Archiv für Mikrobiologie 29, 51-52.

GoLECKI, J. R. (1977). Studies on ultrastructure and composition of cell walls of the cyanobacterium Anacystis nidulans. Archives of Microbiology 114, 3541.

Golecki, J. R. \& DRews, G. (1974). Zur Struktur der Blaualgen-Zellwand. Gefrierätzuntersuchungen an normalen und extrahierten Zellwänden von Anabaena variabilis. Cytobiologie 8, 213-227.

JANSSON, P.-E., KenNe, L., LiedGREN, H., LindBerg, B. \& LöNNGREN, J. (1976). A practical guide to the methylation analysis of carbohydrates. Chemical Communications 1976, no. 8, 1-74.

JENSEN, T. E. \& Sicko, L. M. (1972). The fine structure of the cell wall of Gloeocapsa alpicola, a blue-green alga. Cytobiologie 4, 439-446.

Kellenberger, E., Ryter, A. \& Sechaud, J. (1958). Electron microscope study of DNA containing plasm. Journal of Biophysical and Biochemical Cytology 4, 671-678.

KICKHÖFEN, B. \& WARTH, R. (1968). Eine Trennkammer für die Hochspannungselektrophorese nach dem Michel'schen Prinzip. Journal of Chromatography 33, 558-560.

LOWRY, O. H., ROBERTS, N. R., LEINER, K. Y., WU, M. L. \& FARR, A. L. (1954). The quantitative histochemistry of brain. I. Chemical methods. Journal of Biological Chemistry 207, 1-17.

Potts, M., Ocampo-Friedmann, R., Bowman, M. A. \& TözÜN, B. (1983). Chroococcus S24 and Chroococcus N41 (cyanobacteria): morphological, biochemical and genetical characterization and effects of water stress on ultrastructure. Archives of Microbiology 135, 81-90.

REYNOLDS, E. S. (1963). The use of lead citrate at high $\mathrm{pH}$ as an electron opaque stain in electron microscopy. Journal of Cell Biology 17, 208-212.

RipPKa, R., Deruelles, J., Waterbury, J. B., Herdman, M. \& Stanier, R. Y. (1979). Generic assignments, strain histories and properties of pure cultures of cyanobacteria. Journal of General Microbiology 111, 1-61.

Schmidt, W., Drews, G., Weckesser, J., Fromme, I. \& Borowiak, D. (1980). Characterization of lipopolysaccharides from eight strains of the cyanobacterium Synechococcus. Archives of Microbiology 127, 209-215.

Schnaitman, C. A. (1971). Effect of ethylenediaminetetraacetic acid, Triton X-100 and lysozyme on the morphology and chemical composition of isolated cell wall of Escherichia coli. Journal of Bacteriology 108, 553-562.

SChrader, M., Drews, G., Golecki, J. R. \& WECKESSER, J. (1982 a). Isolation and characterization of sheath from the cyanobacterium Chlorogloeopsis PCC 6912. Journal of General Microbiology 128, 267-272.

Schrader, M., Drews, G., Weckesser, J. \& MAYer, H. $(1982 b)$. Polysaccharide containing 6-O-methylD-mannose in Chlorogloeopsis PCC 6912. Journal of General Microbiology 128, 273-277.

Stanier, R. Y. \& Cohen-BazIRe, G. (1977). Phototrophic procaryotes: the cyanobacteria. Annual Review of Microbiology 31, 225-274.

Trevelyan, W. E., Procter, D. P. \& Harrison, J. S. (1950). Detection of sugars on paper chromatograms. Nature, London 166, 444-445.

VAARA, T. (1982). The outermost surface structures in the chroococcacean cyanobacteria. Canadian Journal of Microbiology 28, 924-941.

WATSON, M. L. (1958). Staining of tissue sections for electron microscopy with heavy metals. Journal of Biophysics, Biochemistry and Cytology 4, 475-478.

WECKesser, J., DReWs, G. \& MAYER, H. (1979). Lipopolysaccharides of photosynthetic prokaryotes. Annual Review of Microbiology 33, 215-239. 